\title{
DETERMINAN MINAT GENERASI MILENIAL DALAM INVESTASI PASAR MODAL DI MASA PANDEMI COVID-19
}

\author{
${ }^{a}$ Rhealin Hening Karatri, ${ }^{b}$ Faridhatun Faidah, cNurzahroh Lailyah \\ abc Universitas Muria Kudus \\ rhealin.hening@umk.ac.id
}

\begin{tabular}{l|l|l} 
Received : September & Accepted : October & Published: December
\end{tabular}

\begin{abstract}
ABSTRAK
Berinvestasi di pasar modal ini mulai diminati oleh generasi milenial, terutama di masa pandemi Covi-19 ini. Argumentasi ini disebabkan karena selama pandemi Covid-19 aktivitas hanya perlu dilakukan di dalam rumah. Tujuan untuk berinvestasi pada pasar modal yaitu menjaga keuntungan bahkan dari rumah saja. Tujuan dari peneltian ini untuk menunjukkan variabel yang mempengaruhi minat generasi milenial untuk investasi di pasar modal di masa pandemi Covid-19. Penelitian ini memakai metode kuantitatif dengan populasi sebanyak 14.478 dengan kriteria generasi milenial yang ada di Kabupaten Kudus dengan rentang usia kelahiran tahun 1982-2002. Teknik pengambilan sampel dengan purposive sampling. Data yang dikumpulkan melalui kuesioner online yang disebar kepada 100 responden milenial di Kabupaten Kudus. Data responden dianalisis memakai regresi linier berganda melalui software SPSS. Hasil penelitian menunjukkan bahwa faktor pengetahuan investasi dan motivasi tidak ada pengaruh pada minat investasi di pasar modal di masa pandemi Covid-19, sedangkan risiko investasi dan kemajuan teknologi berpengaruh pada minat generasi milenial dalam investasi di pasar modal pada masa pandemi Covid-19. Oleh karena itu, para milenial harus tertarik untuk menginvestasikan modalnya di pasar modal guna memberikan kesiapan jangka panjang atau peluang pendanaan di saat krisis dan pandemi. Implikasi dari penelitian ini dapat memberikan kontribusi kepada masyarakat luas khususnya generasi muda agar lebih paham dan berminat dalam investasi di pasar modal.
\end{abstract}

Kata kunci: minat investasi, motivasi, pengetahuan, risiko investasi, kemajuan teknologi

\section{ABSTRACT}

Investing in this capital market began to be in demand by millennials, especially during the Covid-19 pandemic. This argument was caused because during theCovid-19 pandemic activities only need to be done in the house. The goal to invest in the capital market is to keep profits even from home only. The purpose of this research is to show variable that affects millennials' interest in investing in the capital market during the Covid-19 pandemic. This study uses quantitative methods with a population of 14,478 with the criteria of millennials in Kudus Regency with the age range of birth in 1982-2002. Teknik took a sample with purposive sampling. Data was collected through online questionnaires distributed to 100 millennial respondents in Kudus Regency. Respondents' data were analyzed using multiple linear regressions through SPSS software. Research shows that investment knowledge and motivation factors have no influence on investment interest in the capital market in the Covid19pandemic, while investment risks and technological advances affect millennials' interest in investing in the market. the capital during the Covid-19 pandemic. Therefore, millennials should be interested in investing their capital in the capital market to provide long-term readiness or funding opportunities in times of crisis and pandemics. The implications of this research can contribute to the wider community, especially the younger generation to better understand and be interested in investing in the capital market. 
Keywords: investment interests, motivation, knowledge, investment risk, technological advancement

\section{PENDAHULUAN}

Adanya pandemi Covid-19 yang terjadi memberikan dampak negatif bagi kehidupan. Pandemi Covid-19 membuat kehidupan saat ini dituntut untuk mengurangi mobilitas di luar rumah dan dituntut untuk menggunakan sistem digital atau online. Aktifitas online dilakukan mulai dari berinteraksi terhadap sesama, pembelian kebutuhan sehari-hari hingga sistem pembelajaran di dunia pendidikan. Sistem online juga membuat kehidupan bergantung dengan gadget. Gadget banyak digunakan untuk memenuhi kebutuhan melalui transaksi bisnis online sampai dengan investasi pasar modal. Masa pandemi Covid-19 justru meningkatan jumlah investor pasar modal. Hal ini dikarenakan keinginan untuk mendapat keuntungan guna mencukupi kebutuhan dengan tidak keluar rumah. Peningkatan total investor di pasar modal ditunjukkan pada gambar 1 :

\section{Gambar 1. Peningkatan Jumlah Investor Pasar Modal}

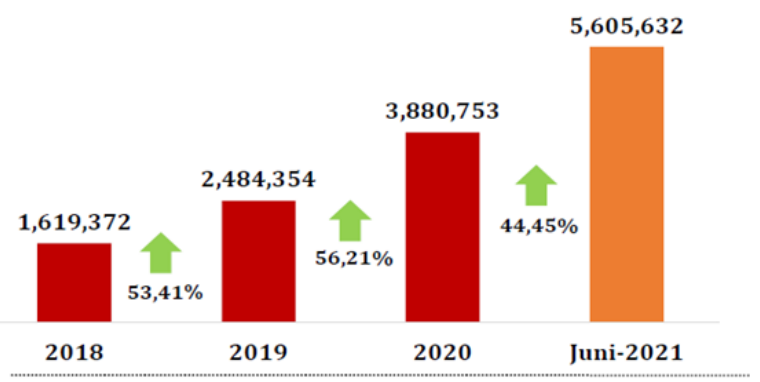

Sumber : www.ksei.co.id (2021)

Berdasarkan dari gambar 1 dapat dijelaskan bahwa terjadi peningkatan jumlah investor pasar modal setiap tahunnya dari 2018 hingga bulan Juni 2021. Tahun 2021 yang baru diperoleh datanya sampai bulan Juni sudah meningkat sampai dengan $44,45 \%$ padahal tahun-tahun sebelumnya meningkat lebih dari $50 \%$ dalam kurun waktu 1 tahun. Hal tersebut menjukkan adanya pandemi Covid-19 ini tidak menurunkan antusias investor dalam berinvestasi di pasar modal. Peningkatan jumlah investor di pasar modal terutama investor muda, yaitu di bawah 30 tahun. Usia tersebut berada pada usia generasi milenial dimana generasi milenial merupakan generasi yang mempunyai rentang waktu tahun kelahiran sekitar tahun 1982 hingga 2002 (Howe \& Strauss, 2000). Berikut untuk gambar demografi investor berdasarkan usia :

Gambar 2. Demografi Investor Pasar Modal

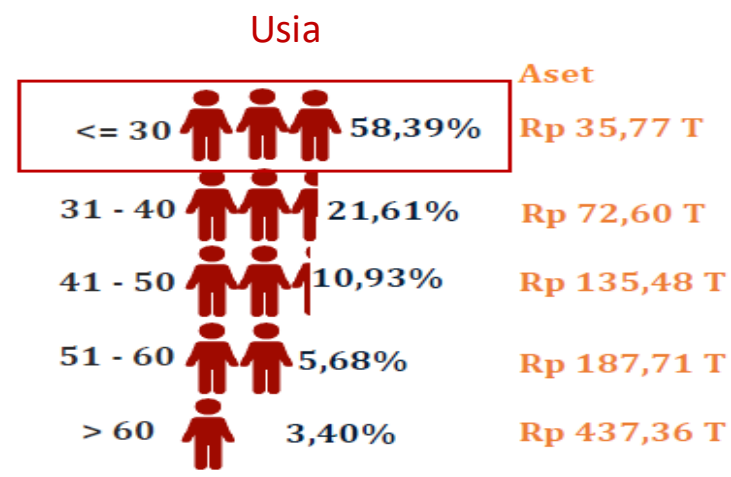

Sumber : www.ksei.co.id (2021) 
Gambar 2 mengenai demografi investor pasar modal didominasi oleh investor usia kurang dari sama dengan 30 tahun sebesar 58,39\% dengan asset 35,77 T di bulan Juni 2021. Hal ini menjukkan bahwa generasi milenial memiliki daya tarik untuk investasi di pasar modal. Generasi milenial melihat adanya fenomena besar pasar modal sebagai peluang untuk persiapan dana jangka panjang serta memperbarui informasi di bidang ekonomi. Presiden Direktur PT Indo Premier Sekuritas Moleonoto menjelaskan bahwa di masa pandemi Covid-19 masyarakat memiliki minat yang tinggi untuk menjadi investor pasar modal. Hal tersebut ditunjukkan dengan jumlah peserta yang ikut serta dalam seminar pasar modal secara virtual semakin meningkat (www.finance.detik.com). Peningkatan investor pasar modal dikarenakan terdapat kesadaran akan pentingnya investasi saat adanya krisis atau pandemi yang dapat menurukan pendapatan. Alasan lain dapat disebabkan adanya work from home (bekerja dari rumah) yang menyebabkan generasi milenial mengalami usaha yang tidak stabil atau pekerjaan terganggu sehingga sadar manfaat investasi untuk jangka panjang.

Minat generasi milenial dalam berinvestasi memiliki banyak faktor yang memengaruhinya. Faktor yang berpengaruh berinvestasi dapat dikarenakan semakin majunya teknologi seperti adanya financial technology yang berkembang secara pesat sehingga dapat memberikan pengaruh berinvestasi secara online (Tumewu ,2019). Banyaknya mengikuti seminar/workshop/pelatihan tentang investasi, membaca buku literasi investasi dapat meningkatkan pengetahuan dalam berinvestasi di pasar modal, adanya sarana, prasarana yang memberikan kemudahan mahasiswa Prodi Akuntansi PTN di Jakarta (Yusuf, 2019). Wibowo \& Purwohandoko (2019) menjelaskan sikap individu yang merasa bahwa modal minimal berinvestasi dianggap tidak mahal jadi dapat meningkatkan minat untuk berinvestasi dan teknik sampling menggunakan nonprobability sampling dengan menggunakan pedoman pengambilan sampel 5-10 dikali jumlah indicator yang ada dengan mengambil nilai paling tinggi lalu 10 dikali jumlah indikator sebanyak 12 sehingga hasilnya adalah angka 120. Sriasih \& Wahyuni (2020) menjelaskan terbatasnya populasi yang digunakan yaitu mahasiswa S1 prodi Akuntansi Universitas Pendidikan Ganesha yang digunakan untuk mengetahui faktor-faktor dari pengetahuan tentang investasi, kemajuan teknologi dan minimnya modal memberikan pengaruh terhadap minat berinvestasi di pasar modal. Pribadi (2020) menerangkan terdapat faktor berpengaruh mulai dari faktor resiko investasi itu sendiri dan faktor syariah yang bmempengaruhi minat generasi muda untuk invetasi di sukuk. Wulandari (2020) hanya menggunakan variabel motivasi dan pengetahuan investasi guna mengetahui minat investasi pasar modal dengan menggunakan sampling jenuh yang diartikan semua anggoota populasi dipakai untuk sampelnya yaitu mahasiswa Program Studi Manajemen Fakultas Ekonomi dan Bisnis Universitas Ahmad Dahlan yang telah mengikuti mata kuliah Teori Portofolio dan Analisis Investasi tahun angkatan 2016. Selain itu penelitian Hati \& Harefa (2019) pada penelitiannya yaitu eksplanatory research dengan pendekatan kuantitatif menerangkan motivasi tidak memberikan pengaruh atas minat investasi muda pada mahasiswi jurusan Manajemen Bisnis Politeknik Negeri Batam yang sudah belajar mata kuliah Keuangan Bisnis dan Pasar Modal. Variabel yang digunakan penelitian Wi \& Anggraeni (2020) menunjukkan adanya faktor yang tidak berpengaruh dengan minat investasi pada karyawan perusahaan yang tersebar di Tangerang dan Jakarta yaitu variabel pengetahuan investasi dan risiko dari berinvestasi. Faktor lain yang tidak berpengaruh terhadap minat investasi yaitu pengetahuan, motivasi investasi, modal investasi minimum, pemahaman tentang investasi, dan profitabilitas (Aini et al., 2019). Penelitian terdahulu tersebut dapat menunjukkan adanya research gap dari penelitian ini yaitu adanya pengkajian terbaru mengenai variabel-variabel yang berpengaruh terhadap minat investasi di pasar modal. Selain itu adanya perluasan sampel dan teknik pengambilan sampling yang berbeda dari penelitian terdahulu.

Tujuan dari penelitian yaitu untuk menunjukkan faktor-faktor yang mempengaruhi minat investasi generasi milenial di masa pandemi Covid-19 dengan variabel motivasi, pengetahuan investasi, risiko investasi dan kemajuan teknologi. Minat investasi pada penelitian ini yaitu kesadaran akan generasi milenial dalam berinvestasi sehingga dapat 
mengetahui faktor apa saja yang mempengaruhinya. Sesuai dengan tujuan tersebut dapat terlihat adanya perbedaan penelitian ini dengan penelitian sebelumnya dimana penelitian ini fokus terhadap minat investasi saat terjadinya pandemi dunia. Selain itu, dari tujuan penelitian dapat terlihat dengan variabel yang digunakan suapaya dapat mengkaji lebih lanjut mengenai relevansi berinvestasi di pasar modal bagi generasi milenial.

\section{Theory of Planned Behavior}

\section{KAJIAN LITERATUR}

Theory of planned behavior yaitu teori hubungan antara sikap dan perilaku seseorang. Teori ini menunjukkan bahwa seseorang bertindak dengan niat dan kontrol yang dirasakan melalui tindakan tertentu dapat dipengaruhi oleh perilaku, norma, dan kontrol perilaku (Timotius Duha, 2016). Theory of Planned Behavior juga menjelaskan minat bertindak (behavioral intention) dapat dipengaruhi oleh kontrol keperilakuan yang dirasakan seseorang (perceivedbehavioralcontrol) sehingga apabila seseorang tertarik untuk berinvestasi akan lebih cenderung untuk mengadopsi perilaku yang dapat memuaskan keinginan investasi di pasar modal (Kusmawati, 2011). Taufiqoh et al., (2019) juga menjelaskan seseorang akan berperilaku apabila ada sesuatu yang menarik minat sehingga akan bertindak memperolehnya. Perilaku tersebut seperti mengikuti seminar online tentang investasi pasar modal, menambah pengetahuan investasi melalui media sosial sehingga akhirnya melakukan investasi pasar (Wibowo \& Purwohandoko, 2019).

\section{Minat}

Minat yaitu adanya dorongan yang kuat dari diri seseorang kepada suatu objek. Minat seseorang berarti rasa yang muncul seperti rasa suka ataupun tertarik akan suatu hal dengan tidak adanya paksaan (Winkel, 2009). Minat seseorang tentang suatu aktifitas akan menyebabkan rasa gembira dan ingin segera mencapainya dan melakukan aktifitas tersebut secara konsisten (Aini et al., 2019). Arikunto (2011) menjelaskan minat adanya seseorang yang sadar pada sesuatu dapat berupa situasi atau masalah yang ada di dirinya. Minat harus direspon dengan sadar sehingga pengetahuan maupun informasi dari objek yang diminati bahkan masalah yang timbul dapat diketahui lebih dulu saat seseorang itu memiliki minat (Susanti et al., 2018).

Taufiqoh et al., (2019) menjelaskan indikator motivasi akan memberikan dorongan kepada seseorang agar berani melakukan investasi sehingga dapat melakukan tingkah laku yang bisa memenuhi keinginannya dalam menanamkan dananya. Selain itu, penelitian Taufiqoh et al., (2019) menjelaskan ukuran variabel yang biasa dipakai untuk pengetahuan investasi yaitu mengerti akan realita yang ada saat berinvestasi, pengetahuan dasar mengenai penilaian investasi pasar modal, tingkat dari risiko investasi yang diukur dari tingkat pengembalian (return) saat berinvestasi. Penelitian Yusuf (2019) juga menggunakan indikator ukuran kemajuan teknologi dari kemudahan lalu kenyamanan, dikarenakan banyak perusahaan sekuritas yang memberikan investasi secara digital sehingga berminat untuk berinvestasi di pasar modal. Sedangkan untuk indikator yang dipakai dalam mengukur pengetahuan investasi yaitu sumber pengetahuan kepustakaan seperti buku atau jurnal investasi dan sumber pengetahuan primer seperti kemudahan sarana prasana dalam melakukan digital investasi (Yusuf, 2019).

\section{Investasi}

Investasi dapat diartikan sebagai seseorang dalam menempatkan dananya dengan tujuan menghasilkan keuntungan di era berikutnya (Herlianto, 2013). Kusmawati (2011) juga menjelaskan bahwa investasi dilakukan karena terdapat kebutuhan yang harus dipenuhi seseorang di masa depan guna meningkatkan nilai asset ataupun menjaga nilai asset yang dimiliki agar dapat digunakan saat krisis ataupun inflasi datang. Investasi dapat diartikan beberapa jumlah dana maupun sumber dana lain yang dipakai oleh suatu perusahaan ataupun seseorang agar mempunyai kekayaan atau aset yang meningkat dengan bersumber dari pembagian hasil investasi seperti dividen di masa yang akan datang (Tumewu, 2019). 


\section{Teori Motivasi}

Teori Motivasi dikatakan adanya dorongan berupa faktor dari dalam diri ataupun luar sehingga dapat tercapainya tujuan agar memenuhi kepuasan akan suatu keinginan (Huda, 2015). Hal tersebut dapat dikaitkan dengan investasi dimana investor dapat terpengaruh untuk berinvestasi ketika dirinya terdorong dengan adanya faktor dari lingkungan investasi atau terdapat perkembangan lingkungan investasi (Malik, 2017).

Seseorang yang berminat sebagai investor mempunyai kriteria yang dapat ditunjukkan dengan seberapa besarnya seseorang tersebut berkeinginan untuk mengetahui akan jenis investasi. Hal itu bisa berawal dari bagaimana cara memperoleh keuntungan dari berinvestasi, kinerja investasi, dan lain-lain. Selain itu dapat diketahui melalui seberapa niat seseorang untuk meluangkan waktunya untuk belajar dan memahami tentang investasi dengan terjun langsung berinvestasi sesuai dengan porsi dan kemampuan mereka sendiri (Kusmawati, 2011).

\section{Pengetahuan Investasi}

Pengetahuan investasi merupakan informasi dimana seorang calon investor dapat menggunakan sebagian dana yang dimilikinya guna memperoleh keuntungan pada jangka panjang. Informasi yang dimaksud dapat dipelajari dengan memahami literatur investasi yang sudah ada kemudian dapat disimpan di dalam ingatan calon investor sampai dengan sukses menjadi seorang investor (Wibowo \& Purwohandoko, 2019). Pengetahuan investasi dapat diperoleh dengan banyak mengikuti seminar/workshop/pelatihan tentang investasi di pasar modal atau belajar melalui buku tentang literasi investasi (Yusuf, 2019).

\section{Risiko Investasi}

Investasi dapat dinilai melalui risiko investasi, model Markowitz menerangkan terdapat risiko investasi yang terbagi menjadi risiko tidak sistematis maupun risiko sistematis. Arti dari risiko tidak sistematis yaitu risiko yang berhubungan dengan adanya pergerakan dari perputaran bisnis ataupun industri tertentu. Risiko di setiap industri memiliki karakteristik masing-masing tergantung pada pengaruh variabel ekonominya. Sedangkan risiko sistematis dapat diartikan sebagai risiko yang bersumber dari luar/eksternal berupa inflasi ataupun keadaan ekonomi secara global. Risiko tersebut dapat dibagi menjadi empat yaitu: risiko tidak memperoleh besarnya dividen, mendapat kerugian saat penjualan saham/capital loss, risiko likuiditas, risiko penghapusan saham-saham (Malik, 2017).

\section{Kemajuan Teknologi}

Saat ini perusahaan sekuritas yang ada sudah memberikan kemudahan bagi seseorang yang berminat investasi seperti memberikan pelayanan system online trading. Online trading ini adalah Langkah baru dalam hal jual beli saham melalui koneksi internet yang ada di gadget. Sistem online melalui aplikasi ini sudah diterapkan dimulai dari tahun 2006 sehingga dapat meningkatkan minat investor untuk transaksi di pasar modal (Tarigan et al., 2019). Kemudahan melalui kemajuan teknologi ini dapat membuat seseorang untuk menanamkan dananya di pasar modal (Tarigan et al., 2019).

\section{Indikator Variabel}

Variabel yang dipakai penelitian ini berupa variabel Motivasi Investasi ( $\left.X_{1}\right)$, Pengetahuan Investasi $\left(X_{2}\right)$, Risiko Investasi $\left(X_{3}\right)$ dan Minat Investasi $\left(Y_{1}\right)$. Skala pengukuran untuk mengukur variabel penelitian menggunakan skala likert 1 sampai 4. Indikator yang dipakai dalam mengukur variabel tersebut yaitu: 
Tabel 1. Indikator Variabel

\begin{tabular}{|c|c|c|c|}
\hline Variabel & & Indikator & Sumber \\
\hline \multirow[t]{5}{*}{ Motivasi Investasi $\left(\mathrm{X}_{1}\right)$} & M1 & $\begin{array}{l}\text { Adanya dorongan individu dalam } \\
\text { melakukan gerakan }\end{array}$ & \multirow{5}{*}{$\begin{array}{l}\text { Aini et al., (2019); } \\
\text { Suyanti \& Hadi } \\
\text { (2019); Taufiqoh } \\
\text { et al., (2019) }\end{array}$} \\
\hline & M2 & $\begin{array}{l}\text { Terdapat perubahan tingkah laku } \\
\text { individu }\end{array}$ & \\
\hline & M3 & $\begin{array}{l}\text { Mulai untuk } \quad \text { Menyusun } \\
\text { perencanaan berinvestasi }\end{array}$ & \\
\hline & M4 & Niat untuk investasi & \\
\hline & M5 & $\begin{array}{l}\text { Tekad dan konsistensi dalam } \\
\text { investasi }\end{array}$ & \\
\hline \multirow[t]{3}{*}{$\begin{array}{l}\text { Pengetahuan } \\
\left(\mathrm{X}_{2}\right)\end{array}$} & PI 1 & $\begin{array}{l}\text { Memiliki pengetahuan cara } \\
\text { melakukan investasi }\end{array}$ & \multirow{3}{*}{$\begin{array}{l}\text { Tumewu, (2019); } \\
\text { Aini et al., (2019) } \\
\text {; Suyanti \& Hadi, } \\
\text { (2019); Yusuf } \\
\text { (2019); Taufiqoh } \\
\text { et al., (2019) }\end{array}$} \\
\hline & $\mathrm{PI} 2$ & $\begin{array}{ll}\text { Memiliki pengetahuan } & \text { terhadap } \\
\text { tipe-tipe } & \text { investasi } \\
\text { pada asset finansial } & \end{array}$ & \\
\hline & PI3 & $\begin{array}{ll}\text { Memiliki pengetahuan } & \text { terhadap } \\
\text { konsep } & \text { investasi } \\
\text { pada asset finansial } & \\
\end{array}$ & \\
\hline \multirow[t]{3}{*}{ Risiko Investasi $\left(\mathrm{X}_{3}\right)$} & $\mathrm{RI} 1$ & $\begin{array}{l}\text { Adanya keuntungan yang } \\
\text { menjanjikan dalam berinvestasi di } \\
\text { pasar modal }\end{array}$ & \multirow[t]{3}{*}{$\begin{array}{l}\text { Hati \& Harefa, } \\
\text { (2019); Taufiqoh } \\
\text { et al., (2019) }\end{array}$} \\
\hline & $\mathrm{RI} 2$ & $\begin{array}{l}\text { Memperoleh } \\
\text { sebanyak } 10 \% \text { dengan toleransi } \\
\text { kerugian } 5 \% \text { saat nilai investasi } \\
\text { bisa berkurang dari fluktuasi } \\
\text { pasar }\end{array}$ & \\
\hline & RI 3 & $\begin{array}{l}\text { Dapat dicairkan dana investasi } \\
\text { saat nilai investasi menurun } \\
\text { sebesar } 5 \% \text { dari nilai investasi }\end{array}$ & \\
\hline \multirow[t]{3}{*}{ Kemajuan Teknologi $\left(\mathrm{X}_{4}\right)$} & KT 1 & $\begin{array}{l}\text { Persepsi akan sarana yang ada } \\
\text { merupakan dampak dari } \\
\text { kemajuan teknologi }\end{array}$ & \multirow{3}{*}{$\begin{array}{l}\text { Tandio } \\
\text { Widanaputra } \\
\text { (2016); } \\
\text { Yusuf (2019) }\end{array}$} \\
\hline & KT 2 & $\begin{array}{l}\text { Kemudahan dalam melakukan } \\
\text { investasi melalui mobile/gadget }\end{array}$ & \\
\hline & KT 3 & $\begin{array}{l}\text { Ketersediaan fitur online investasi } \\
\text { yang simple dan mudah dipahami }\end{array}$ & \\
\hline \multirow[t]{4}{*}{ Minat Investasi $\left(\mathrm{Y}_{1}\right)$} & MI 1 & $\begin{array}{l}\text { Tertarik berinvestasi dikarenakan } \\
\text { informasi yang diperoleh }\end{array}$ & \multirow{4}{*}{$\begin{array}{l}\text { Hati \& Harefa } \\
\text { (2019); Aini et al., } \\
\text { (2019); Tumewu, } \\
\text { (2019); Suyanti \& } \\
\text { Hadi (2019); } \\
\text { Taufiqoh et al., } \\
\text { (2019); Yusuf } \\
\text { (2019) }\end{array}$} \\
\hline & MI 2 & $\begin{array}{l}\text { Berminat investasi dikarenakan } \\
\text { investasi pasar modal menjajikan } \\
\text { apalagi untuk jangka panjang }\end{array}$ & \\
\hline & MI3 & $\begin{array}{l}\text { Sudah mempelajari informasi } \\
\text { investasi pasar modal }\end{array}$ & \\
\hline & MI 4 & $\begin{array}{l}\text { Investasi pasar modal adalah } \\
\text { investasi yang menarik dan } \\
\text { menantang }\end{array}$ & \\
\hline
\end{tabular}

Sumber : Berbagai jurnal yang diolah (2021) 


\section{Pandemi Covid-19}

Minat investasi dipengaruhi oleh beberapa variabel salah satunya terdapat motivasi yang berpengaruh dalam minat investasi pasar modal (Cahya \& Kusuma, 2019). Luki Zulaika (2017) menjelaskan motivasi mahasiswa STIE Kesuma Negara Blitar berpengaruh terhadap minat investasi pasar modal. Mastura et al., (2020) menjelaskan bahwa motivasi mahasiswa FIA maupun mahasiswa FEB UNISMA memberikan pengaruh terhadap ketertarikan investasi pasar modal. Berdasarkan penelitian sebelumnya, dibuat hipotesis sebagai berikut:

$\mathrm{H}_{1}$ : Motivasi berpengaruh positif terhadap minat generasi milenial dalam investasi pasar modal di masa pandemi Covid-19.

\section{Pengaruh Pengetahuan Investasi terhadap minat Investasi Pasar Modal Generasi Milenial di Masa Pandemi Covid-19}

Variabel lain yang mempengaruhi minat investasi adalah pengetahuan investasi yang diperoleh oleh seseorang (Hidayat et al., 2019). Suyanti \& Hadi (2019) menujukkan bahwa pengetahuan investasi mahasiswa ekonomi STKIP Tulungagung diberikan pengaruh terhadap ketertarikan dalam investasi pasar modal. Penelitian Y. Witha et al., (2020) juga menjelaskan dapat berpengaruh pada ketertarikan minat berinvestasi pasar modal di mahasiswa FEB Universitas Papua. Berdasarkan penelitian yang ada, sehingga dapat dibuat hipotesis kedua yaitu:

$\mathrm{H}_{2}$ : Pengetahuan investasi mempengaruhi secara positif minat generasi milenial dalam investasi pasar modal di masa pandemi Covid-19.

\section{Pengaruh Risiko Investasi terhadap minat Investasi Pasar Modal Generasi Milenial di Masa Pandemi Covid-19}

Risiko investasi memiliki pengaruh dalam minat investasi pasar modal dikarenakan adanya persepsi risiko akan return yang menguntungkan bagi investor (Deviyanti et al., 2017). Penelitian Yani et al., (2020) menjelaskan risiko investasi memberikan perngaruh secara pasti pada ketertarikan minat investasi pasar modal di investor pemula Universitas Warmadewa. Risiko investasi memengaruhi ketertarikan mahasiswa investasi di pasar modal di PT Phintraco Sekuritas Semarang (Listyani et al., 2019). Sehingga hipotesis 3 yaitu:

$\mathrm{H}_{3}$ : Risiko investasi mepengaruhi secara positif minat generasi milenial dalam investasi pasar modal di masa pandemi Covid-19.

\section{Pengaruh Kemajuan Teknologi terhadap minat Investasi Pasar Modal Generasi Milenial di Masa Pandemi Covid-19}

Teknologi yang semakin maju memberikan pengaruh kepada minat individu dalam berinvestasi, dengan adanya media digital seperti kemudahan dalam mengakses website atau aplikasi investasi (Rahadi \& Stevanus, 2020).

Penelitian ini sesuai dengan hasil Cahya \& Kusuma (2019) menjelaskan majunya teknologi dari "Yuk Nabung Saham" mempengaruhi minat investasi anak muda Y di Kota Kudus. Pengaruh kemajuan teknologi juga meningkatkan ketertarikan investasi generasi milenial mahasiswa ekonomi dan bisnis Universitas Muhamadiyah Tangerang (Negara \& Febrianto, 2020). Penelitian yang berbeda ditunjukkan Tandio \& Widanaputra (2016) bahwa majunya teknologi tidak memengaruhi tertarik berinvestasi pasar modal oleh mahasiswa FEB Universitas Udayana. Berdasarkan penelitian sebelumnya, maka dirumuskan hipotesis sebagai berikut:

$\mathrm{H}_{4}$ : Kemajuan teknologi memengaruhi secara positif minat generasi milenial dalam investasi pasar modal di masa pandemi Covid-19. 


\section{METODE}

Penelitian ini meneliti di faktor-faktor yang memberikan pengaruh minat generasi milenial dalam investasi pasar modal di masa pandemi Covid-19. Metode penelitian yang peneliti gunakan adalah metode kuantitatif. Sampel yang dipakai yaitu generasi milenial yang berdomisili di Kabupaten Kudus. Teknik purposive sampling yang dipakai yaitu sebagai teknik pengambilan sampel. Kriteria yang ditentukan dalam pengambilan sampel adalah sebagai berikut:

1. Sampel merupakan generasi milenial (kelahiran antara 1982 - 2002) di Kabupaten Kudus yang tertarik untuk investasi di pasar modal di masa pandemi Covid-19.

2. Sampel adalah mahasiswa/i ekonomi, karyawan perbankan, dan pebisnis yang berdomisili di Kabupaten Kudus.

3. Sampel bersedia mengisi kuesioner yang diberikan peneliti.

Berdasarkan kriteria diatas, diperoleh populasi sebanyak 14.478, kemudian jumlah populasi tersebut ditentukan total sampel dengan rumus Slovin dengan margin of error $10 \%$ sebagai berikut:

$$
\mathrm{n}=\frac{\mathrm{N}}{\left(N \cdot \mathrm{d}^{2}\right)+1}=\frac{14 \cdot 478}{(14 \cdot 478 \cdot 0,01)+1}=99,31
$$

Jika dilakukan pembulatan maka sampel minimal dari populasi sebesar 14.478 pada margin of error $10 \%$ sebesar 100 . Data dikumpulkan dengan kuesioner melalui google form yang dibagikan kepada 100 (seratus) milenial di Kabupaten Kudus.

Variabel yang dipakai untuk mengukur tertarik milenial dalam investasi pasar modal selama pandemi Covid19 adalah berupa motivasi, pengetahuan investasi, risiko investasi, dan kemajuan teknologi. Dokumen untuk penelitian ini dijadikan satu dengan menyebarkan kuesioner online melalui formulir Google. Dokumen hasil pengukuran yang digunakan adalah skala likert dengan rentang skor 1-4. Penelitian ini menggunakan uji instrumental berupa uji validitas dan uji reliabilitas. Alat analisis penelitian yaitu menggunakan regresi linier berganda dari software SPSS terbaru untuk menguji variabel-variabel yang minat generasi milenial dalam investasi pasar modal di masa pandemi Covid-19. Hasil dari hipotesis yang sudah dibuat diuji dengan Uji F dan Uji Koefisien Determinasi melalui SPSS.

Analisis regresi linear berganda menjadi metode analisis yang digunakan peneliti dengan persamaan regresi sebagai berikut:

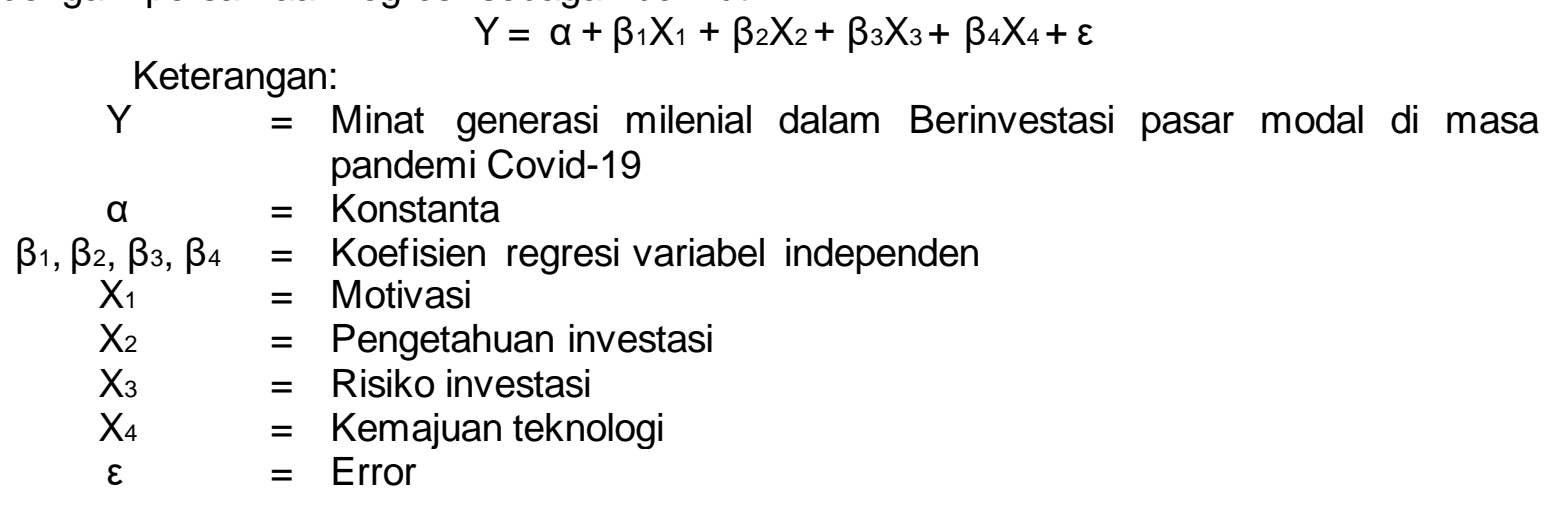

HASIL PENELITIAN DAN PEMBAHASAN

Narasumber pada penelitian ini terbagi menjadi beberapa karakterisktik. Karakteristik tersebut untuk melihat kualitas responden yang mengisi angket penelitian. Berikut hasil karakteristik responden:

Tabel 1. Hasil Karakteristik Responden 


\begin{tabular}{|c|c|c|c|c|c|}
\hline \multicolumn{6}{|c|}{ Jenis Kelamin } \\
\hline & & Frequency & Percent & $\begin{array}{c}\text { Valid } \\
\text { Percent }\end{array}$ & $\begin{array}{c}\text { Cumulative } \\
\text { Percent }\end{array}$ \\
\hline \multirow[t]{3}{*}{$\overline{\text { Valid }}$} & Laki-Laki & 42 & 42,0 & 42,0 & 42,0 \\
\hline & Perempuan & 58 & 58,0 & 58,0 & 100,0 \\
\hline & Total & 100 & 100,0 & 100,0 & \\
\hline \multicolumn{6}{|c|}{ Usia } \\
\hline & & & & Valid & Cumulative \\
\hline & & Frequency & Percent & Percent & Percent \\
\hline \multirow[t]{7}{*}{$\overline{\text { Valid }}$} & $<20$ Tahun & 9 & 9,0 & 9,0 & 9,0 \\
\hline & 20-30 Tahun & 87 & 87,0 & 87,0 & 96,0 \\
\hline & >30 Tahun & 4 & 4,0 & 4,0 & 100,0 \\
\hline & Total & 100 & 100,0 & 100,0 & \\
\hline & \multicolumn{5}{|c|}{ Pendidikan Terakhir } \\
\hline & & & & Valid & Cumulative \\
\hline & & Frequency & Percent & Percent & Percent \\
\hline \multirow[t]{5}{*}{$\overline{\text { Valid }}$} & SMA Sederajad & 38 & 38,0 & 38,0 & 38,0 \\
\hline & Akademi/Diploma & 8 & 8,0 & 8,0 & 46,0 \\
\hline & & 51 & 51,0 & 51,0 & 97,0 \\
\hline & S2 / S3 & 3 & 3,0 & 3,0 & 100,0 \\
\hline & Total & 100 & 100,0 & 100,0 & \\
\hline \multicolumn{6}{|c|}{ Status } \\
\hline & & & & Valid & Cumulative \\
\hline & & Frequency & Percent & Percent & Percent \\
\hline \multirow[t]{6}{*}{$\overline{\text { Valid }}$} & Pelajar & 12 & 12,0 & 12,0 & 12,0 \\
\hline & Mahasiswa & 51 & 51,0 & 51,0 & 63,0 \\
\hline & Pegawai Swasta & 20 & 20,0 & 20,0 & 83,0 \\
\hline & BUMN / PNS & 8 & 8,0 & 8,0 & 91,0 \\
\hline & Lainnya & 9 & 9,0 & 9,0 & 100,0 \\
\hline & Total & 100 & 100,0 & 100,0 & \\
\hline
\end{tabular}

Sumber : Data diolah, 2021

Tabel 1 dapat dijelaskan bahwa dari 100 (serratus) responden yang berjender lakilaki sebesar $42 \%$ selain itu yang bergender perempuan sebanyak $58 \%$ sehingga bisa disimpulkan responden mayoritas berjenis kelamin perempuam. Responden diklasifikasi dengan 3 klasifikasi umur, responden berusia $<20$ tahun sebesar 9\%, usia antara 20 hingga 30 tahun sebanyak $87 \%$, sedangkan yang berusia > 30 tahun sebanyak $4 \%$ dapat dilihat kebanyakan narasumber berusia 20 - 30 tahun.

Klasifikasi menurut pendidikan terakhir menunjukkan pendidikan terakhir SMA sederajad sebesar 38\%, Akademi/Diploma sebesar 8\%, dan untuk Pendidikan S1 sebesar $51 \%$, sedangkan S2/S3 sebesar 3\%. Klasifikasi pendidikan terakhir dapat ditarik kesimpulan bahwa responden berdominan di pendidikan terkahir S1. Responden diklasifikasi berdasarkan status dapat menunjukkan status sebagai pelajar sebesar $12 \%$, mahasiswa sebesar 51\%, pegawai swasta sebesar 20\%, dan bekerja di instansi BUMN atau PNS sebesar $8 \%$, sedangkan yang bekerja selian itu terdapat $9 \%$. Hasil pengklasifikasian responden berdasarkan status bahwa responden didominasi oleh mahasiswa.

Dalam penelitian ini dalam menguji validitas menggunakan korelasi product moment (pearson). Syarat nilai dikatakan valid dengan menggunakan ketentuan rhitung $>$ rtabel. Cara menghitung rhitung dilihat terlebih dahulu dari tabel product moment untuk mengetahui $r_{\text {tabel }}($ $a, n-2$ ). Diketahui $n=100$ dan $a=5 \%$, setiap item rhitung lebih besar dari rtabel jadi item tersebut valid. Berikut ini hasil uji validitas:

Tabel 2. Uji Validitas 


\begin{tabular}{|c|c|c|c|c|}
\hline & Item & $\mathbf{R}_{\text {hitung }}$ & $\mathbf{R}_{\text {tabel }}$ & Keterangan \\
\hline Variabel & M1 & 0,532 & 0,202 & VALID \\
\hline \multirow[t]{4}{*}{ Motivasi } & M 2 & 0,553 & 0,202 & VALID \\
\hline & M3 & 0,539 & 0,202 & VALID \\
\hline & M 4 & 0,572 & 0,202 & VALID \\
\hline & M 5 & 0,651 & 0,202 & VALID \\
\hline \multirow{3}{*}{$\begin{array}{l}\text { Variabel } \\
\text { Pengetahuan } \\
\text { Investasi } \\
\end{array}$} & $\mathrm{PI} 1$ & 0,547 & 0,202 & VALID \\
\hline & $\mathrm{PI} 2$ & 0,554 & 0,202 & VALID \\
\hline & $\mathrm{PI} 3$ & 0,533 & 0,202 & VALID \\
\hline Variabel & $\mathrm{RI} 1$ & 0,573 & 0,202 & VALID \\
\hline \multirow[t]{2}{*}{ Risiko Investasi } & $\mathrm{RI} 2$ & 0,537 & 0,202 & VALID \\
\hline & $\mathrm{RI} 3$ & 0,539 & 0,202 & VALID \\
\hline \multirow{3}{*}{$\begin{array}{l}\text { Variabel } \\
\text { Kemajuan } \\
\text { Teknologi } \\
\end{array}$} & KT 1 & 0,534 & 0,202 & VALID \\
\hline & KT 2 & 0,588 & 0,202 & VALID \\
\hline & KT 3 & 0,587 & 0,202 & VALID \\
\hline \multirow{4}{*}{$\begin{array}{l}\text { Variabel } \\
\text { Minat Investasi } \\
\text { Pasar Modal }\end{array}$} & MIPM 1 & 0,556 & 0,202 & VALID \\
\hline & MIPM 2 & 0,542 & 0,202 & VALID \\
\hline & MIPM 3 & 0,570 & 0,202 & VALID \\
\hline & MIPM 4 & 0,549 & 0,202 & VALID \\
\hline
\end{tabular}

Sumber: Data diolah, 2021

Tabel 2 dari uji validitas diketahui bahwa 18 item dalam instrumen penelitian motivasi, pengetahuan investasi, risiko investasi, kemajuan teknologi, dan minat investasi pasar modal dinyatakan valid secara keseluruhan dikarenakan nilai $r_{\text {hitung }}>r_{\text {tabel }}(0,202)$. Hal ini dapat diartikan penelitian ini tepat dalam menggunakan item pernyataan sebanyak 18 item pernyataan tersebut.

Penelitian ini memaikai uji reliabilitas. Ghozali (2011) menjelaskan uji ini bertujuan mencari tahu tingkat reliabilitas alpha yang dibagi menjadi 3, yaitu :

1) Cronbach's Alpha $<0,60$ yaitu tidak reliabel

2) Cronbach's Alpha $0,60-0,79$ yaitu reliabel

3) Cronsbach's Alpha $0,80-1,00$ yaitu sangat reliabel

Berikut uji reliabilitas dari penelitian ini :

Tabel 3. Uji Reliabilitas

\begin{tabular}{lllc}
\hline \multicolumn{1}{c}{ Uji Reliabilitas } & $\begin{array}{c}\text { Cronbach's } \\
\text { Alpha }\end{array}$ & N of Item & Keterangan \\
\hline Motivasi & 0,769 & 5 & Reliabel \\
Pengetahuan Invesatasi & 0,782 & 3 & Reliabel \\
Risiko Investasi & 0,887 & 3 & Sangat Reliabel \\
Kemajuan Teknologi & 0,819 & 3 & Sangat Reliabel \\
Minat Investasi Pasar & 0,949 & 4 & Sangat Reliabel \\
Modal & & &
\end{tabular}

Sumber : Data diolah, 2021

Hasil dari tabel 3 bahwa 18 item instrumen penelitian pada variabel motivasi, pengetahuan investasi, risiko investasi, kemajuan teknologi, dan minat invesatasi pasar modal dinyatakan reliabel karena Cronbach's Alpha >0,70.

Analisis Deskriptif digunakan untuk mengetahui jumlah data yang dapat diproses dan tidak dapat diproses. Selain itu untuk mengetahui mean dan nilai standar deviation.

Tabel 4. Analisis Deskriptif 


\section{Descriptive Statistics}

\begin{tabular}{lccccc}
\hline & N & Minimum & Maximum & Mean & $\begin{array}{c}\text { Std. } \\
\text { Deviation }\end{array}$ \\
\hline Total Motivasi & 100 & 7,00 & 20,00 & 17,1800 & 2,26693 \\
Total Pengetahuan Investasi & 100 & 5,00 & 12,00 & 10,4500 & 1,29002 \\
Total Risiko Investasi & 100 & 4,00 & 12,00 & 10,1400 & 1,33348 \\
Total Kemajuan Teknologi & 100 & 5,00 & 12,00 & 10,3500 & 1,35121 \\
Total Investasi Pasar Modal & 100 & 6,00 & 16,00 & 13,9900 & 1,72618 \\
Valid N (listwise) & 100 & & & & \\
\hline
\end{tabular}

Sumber : Data diolah, 2021

Hasil deskriptif motivasi pada kaum anak muda di era pandemi Covid-19 di tabel 4 menunjukkan jumlah data sebanyak 100 responden dengan $\mathrm{N}$ valid dapat dikatakan bahwa data yang tidak terdeteksi sebanyak 0 . Mean motivasi sebesar 17,1800 . Rasio minimum variabel motivasi sebesar 7,00 sedangkan rasio maksimum motivasi sebesar 20,00 . Nilai standar deviationnya adalah 2,26693.

Tabel 4 yang menunjukkan hasil deskriptif pengetahuan investasi pada kaum anak muda di era pandemi Covid-19 yaitu data yang terproses sebanyak 100 dan N missing sebanyak 0 . Mean pengetahuan investasi sebesar 10,4500. Rasio minimum pengetahuan investasi sebesar 5,00 dan rasio maksimum variabel pengetahuan investasi sebesar 12,00. Nilai standar deviationnya sebesar 1,29002.

Risiko investasi pada kaum anak muda di era pandemi Covid-19, hasil deskriptif di pada tebel 4 diketahui total berkas terproses berjumlah 100 dan $\mathrm{N}$ missing berjumlah 0 . Rata-rata Risiko Investasi sebesar 10,1400. Variabel risiko investasi memiliki rasio minimum sebesar 4,00 sedangkan untuk rasio maksimum risiko investasi sebesar 12,00 . Nilai standar deviationnya yaitu 1,33348 .

Tabel 4 juga menunjukkan hasil deskriptif kemajuan teknologi kaum anak muda di era pandemi Covid-19 dengan total berkas terproses sejumlah 100 responden dengan $\mathrm{N}$ valid sebanyak 0 . Mean kemajuan teknologi sebesar 10,3500. Rasio minimum variabel kemajuan teknologi sebesar 5,00. Kemajuan teknologi memiliki rasio maksimum sebesar 12,00 dan nilai standar deviationnya adalah 1,35121.

Selain itu, hasil deskriptif investasi pasar modal pada kaum anak muda di era pandemi Covid-19 diketahui total berkas terproses berjumlah 100 responden dengan $\mathrm{N}$ valid sebanyak 0 . Mean dari investasi pasar modal sebesar 13,9900. Nilai rasio minimum sebesar 6,00 dan untuk rasio maksimumnya sebesar 16,00 dengan nilai standar deviationnya sebesar 1,72618.

Analisis statistik yang digunakan dalam penelitian ini merupakan regresi linier berganda. Analisis ini digunakan untuk mengetahui pengaruh variabel bebas terhadap variabel terikat. Data yang diperoleh dari masing-masing indeks variabel akan dihitung secara simultan menggunakan persamaan regresi linier berganda.

Hasil perhitungan dengan menggunakan program SPSS versi 22 memberikan hasil regresi sebagai berikut:

Tabel 5. Hasil Analisis Regresi Linear Berganda

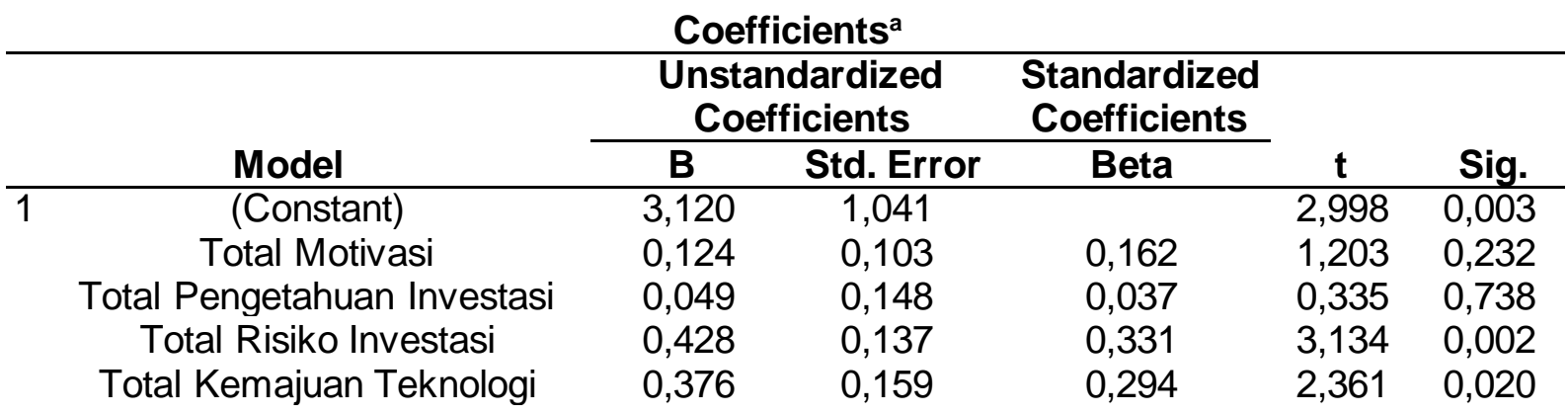


Sumber : Data diolah, 2021

a. Dependent Variable: Total Investasi Pasar Modal

Persamaan regresi yang terbentuk pada uji regresi berdasarkan tabel 7 , yaitu :

$\begin{aligned} Y & =3,120+0,124 X_{1}+0,049 X_{2}+0,428 X_{3}+0,376 X_{4}+\varepsilon \\ \text { Dimana } & : \\ Y & =\text { Investasi Pasar Modal } \\ X_{1} & =\text { Motivasi } \\ X_{2} & =\text { Pengetahuan Investasi } \\ X_{3} & =\text { Risiko Investasi } \\ X_{4} & =\text { Kemajuan Teknologi } \\ \varepsilon & =\text { Error }\end{aligned}$

Konstanta sebesar 3,120 dan bertanda positif menandakan perhitungan investasi pasar modal dengan persamaan regresi. Konstanta tersebut menunjukkan bahwa apabila variabel motivasi, pengetahuan investasi, risiko investasi, dan kemajuan teknologi diasumsikan tetap atau nol, sehingga konstanta akan dapat menaikan minat investasi pasar modal generasi milenial di masa pandemi Covid-19 sebesar 3,120.

Motivasi memiliki koefisien regresi sebesar 0,124 yang berarti setiap penambahan motivasi sebesar satu persen akan menaikan minat investasi pasar modal generasi milenial di masa pandemi Covid-19 sebesar 0,124. Koefisien regresi pengetahuan investasi menjukkan sejumlah 0,049 yang berarti setiap penambahan pengetahuan investasi sebesar satu persen akan menaikan minat investasi pasar modal generasi milenial di masa pandemi Covid-19 sebesar 0,049 . Koefisien regresi risiko investasi sebesar 0,428 dapat dinyatakan bahw setiap penambahan risiko investasi sebesar satu persen akan menaikan minat investasi pasar modal generasi milenial di masa pandemi Covid-19 sebesar 0,428. Koefisien regresi kemajuan teknologi sebesar 0,376 dapat didefinisikan setiap bertambah maju teknologi sebesar satu persen akan menaikan minat investasi pasar modal generasi milenial di masa pandemi Covid-19 sebesar 0,376.

Hasil perhitungan yang dilaporkan pada Tabel 5 menunjukkan bahwa nilai signifikan dari variabel dinamis adalah 0,232 . Nilaii signifikansii sebesari $0,232(>0,05)$, menunjukkan hipotesis ivariabel dinamis $\left(\mathrm{H}_{1}\right)$ memiliki kandungan "Motivasi itidak berpengaruh terhadap minat investasi di pasar modal pada generasi milenial di masa pandemi Covid-19", hipotesis dinamis $\left(H_{1}\right)$ ditolak. Kemudian untuk variabel pengetahuan investasi yaitu sebesar 0,738. Hasil penelitian untuk nilai signifikansi variabel pengetahuan investasi sebesar 0,738 (> 0.05 ), sehingga hipotesis pengetahuan investasi $\left(\mathrm{H}_{2}\right)$ yang dinyatakan "Pengetahuan investasi tidak berpengaruh terhadap minat investasi pasar modal pada generasi milenial di masa pandemi Covid-19", Hipotesis $\left(\mathrm{H}_{2}\right)$ ditolak. Kemudian hasil perhitungan variabel risiko investasi diperoleh nilai signifikan sebesar 0,002 . Nilai signifikan variabel risiko investasi dalam penelitian ini adalah $0,002(<0,05)$, oleh karena itu asumsi risiko investasi $\left(\mathrm{H}_{3}\right)$ memiliki arti "Risiko investasi mempengaruhi tingkat bunga investasi" investasi di pasar modal bagi kaum milenial padaimasa pandemi Covid-19, "Risiko investasi hipotetis $\left(\mathrm{H}_{3}\right)$ diterima. Variabel kemajuan teknologi yang disajikan pada Tabel 5 besar nilai signifikansi yaitu 0,020 . Hasil yang diperoleh memberikan nilai signifikansi variabel kemajuan teknologi sebesar $0,020(<0,05)$, sehingga hipotesis untuk variabel kemajuan teknologi $\left(\mathrm{H}_{4}\right)$ memiliki kandungan "Kemajuan teknis berpengaruh terhadap investasi di pasar modal pada generasi milenial di masa pandemi Covid-19", Menerima hipotesis kemajuan teknologi $\left(\mathrm{H}_{4}\right)$.

Selanjutnya, pengujian hipotesis ini dilakukan dengan uji $F$ dan uji koefisien determinasi. Uji F digunakan mengetahui apakah terdapat pengaruh antara variabel $X_{1}$ motivasi, variabel $X_{2}$ pengetahuan investasi, variabel $X_{3}$ risiko investasi, variabel $X_{4}$ kemajuan teknologi secara simultan terhadap variabel $Y$ (minat investasi pasar modal) pada generasi milenial di masa pandemi Covid-19. Berdasarkan hasil perhitungan program SPSS ditunjukkan oleh tabel 6 , sebagai berikut: 


\begin{tabular}{llrrrrc}
\multicolumn{7}{c}{ Tabel 6. Uji F } \\
ANOVA $^{\mathbf{a}}$ \\
\hline Model & & Sum of & & Mean & & \\
\hline 1 & Squares & df & Square & F & Sig. \\
\hline & Regression & 164,342 & 4 & 41,085 & 29,875 & $0,000^{\mathrm{b}}$ \\
& Residual & 130,648 & 95 & 1,375 & & \\
& Total & 294,990 & 99 & & & \\
\hline
\end{tabular}

Sumber : Data diolah, 2021

a. Dependent Variable: Total Investasi Pasar Modal

b. Predictors : (Constant), Total Kemajuan Teknologi, Total Risiko Investasi, Total

Pengetahuan Investasi, Total Motivasi

Hasil dari uji ANOVA atau $F$ test mendapatkan F hitung sebesar 29,875 dan nilai probabilitasnya 0,000 , nilai probabilitas jauh lebih kecil dari 0,05 . Hal ini menujukkan bahwa semua hipotesis memiliki pengaruh antara variabel $X_{1}$ motivasi, variabel $X_{2}$ pengetahuan investasi, variabel $X_{3}$ risiko investasi, variabel $X_{4}$ kemajuan teknologi secara bersama-sama terhadap variabel $Y$ (minat investasi pasar modal) pada kaum anak muda di era pandemi Covid-19" dapat diterima.

Koefisien Determinasi digunakan gunamengetahui berapa besar kemampuan variabel-variabel bebas dalam menerangkan variabel yang terikat. Nilai determinasi ditentukan melalui hasil dari nilai Adjusted $R$ Square.

\section{Tabel 7. Uji Koefisien Determinasi} Model Summary

\begin{tabular}{ccccc}
\hline Model & $\mathbf{R}$ & $\mathbf{R}$ Square & $\begin{array}{c}\text { Adjusted R } \\
\text { Square }\end{array}$ & $\begin{array}{c}\text { Std. Error of the } \\
\text { Estimate }\end{array}$ \\
\hline 1 & $0,746^{\mathrm{a}}$ & 0,557 & 0,538 & 1,17271 \\
\hline
\end{tabular}

Sumber: Data diolah, 2021

a. Predictors: (Constant), Total Kemajuan Teknologi, Total Risiko Investasi,

Total Pengetahuan Investasi, Total Motivasi

Tabel 7 menunjukkan nilai koefisien determinasi yang sesuai dengan (adjusted $R^{2}$ ) adalah 0,538 . Nilai (adjusted $R^{2}$ ) berada diantara $0 \leq 0,538 \leq 1$. Hal ini dapat disimpulkan bahwa variasi dari semua variabel bebas (motivasi, pengetahuan investasi, risiko investasi, dan kemajuan teknologi) dapat menerangkan variabel terikat (minat investasi pasarmodal) sebesar 0,538 sedangkan sisanya yaitu sebesar 0,462 diterangkan oleh variabel lain yang tidak terdapat di penelitian ini.

\section{a) Pengaruh Motivasi terhadap minat Investasi Pasar Modal Generasi Milenial di Masa Pandemi Covid-19}

Hasil perhitungan menunjukkan bahwa hipotesis variabel dinamis $\left(\mathrm{H}_{1}\right)$ memiliki kandungan "Motivasi tidak berpengaruh terhadap minat investasi di pasar modal pada generasi milenial di masa pandemi Covid-19", sehingga hipotesis dinamis $\left(\mathrm{H}_{1}\right)$ ditolak. Hal ini tidak sesuai dengan teori motivasi yang dikemukakan oleh Malik (2017) yang menjelaskan seseorang yang menjadi investor dipengaruhi dari lingkungan investasi itu sendiri dan juga perkembangan lingkungan investasi tersebut sehingga tergerak dan termotivasi untuk investasi. Motivasi yang diberikan tidak merangsang minat generasi milenial untuk berinvestasi di pasar modal di masa pandemi Covid-19, di mana generasi milenial tidak sepenuhnya atau belum mau untuk memulai berinvestasi di pasar modal pada saat terjadinya pandemi Covid-19. Hal ini berbeda dengan penelitian Luki Zulaika (2017) yang menjelaskan motivasi mahasiswa STIE Kesuma Negara Blitar berpengaruh terhadap minat berinvestasi di pasar modal. Mastura et al., (2020) menjelaskan bahwa motivasi berpengaruh terhadap minat mahasiswa FIA dan FEB UNISMA untuk berinvestasi di pasar modal. 
Di sisi lain, penelitian ini didukung oleh temuan Hermanto (2017) bahwa motivasi mahasiswa ekonomi Universitas Esa Unggul tidak mempengaruhi minat berinvestasi di pasar modal. Aini et al., (2019)juga menunjukkan bahwa motivasi mahasiswa Fakultas Ekonomika dan Bisnis Kota Malang tidak mempengaruhi minat mereka untuk berinvestasi di pasar modal. Dinamika ini tidak mempengaruhi generasi milenial yang tertarik berinvestasi pasar modal di kalangan jurusan manajemen bisnis di Politeknik Negeri Batam (Hati \& Harefa, 2019). Temuan ini menunjukkan bahwa generasi milenial Kabupaten Kudus dengan sebagian besar belum atau tidak termotivasi untuk menggunakan dananya untuk berinvestasi di pasar modal selama pandemi Covid- 19.

\section{b) Pengaruh Pengetahuan Investasi terhadap minat Investasi Pasar Modal Generasi Milenial di Masa Pandemi Covid-19}

Hasil perhitungan menunjukkan bahwa pengetahuan investasi $\left(\mathrm{H}_{2}\right)$ yang berbunyi "Pengetahuan investasi tidak berpengaruh terhadap minat investasi pasar modal pada generasi milenial di masa pandemi Covid-19", sehingga Hipotesis $\left(\mathrm{H}_{2}\right)$ ditolak. Wibowo \& Purwohandoko (2019) menjelaskan dalam teorinya bahwa informasi yang didapat dari berbagai pembelajaran lalu dapat diterima maka dapat menjadi sebuah pengetahuan untuk individu. Penelitian ini menjelaskan informasi yang diserap oleh generasi milenial lebih kepada informasi mengenai pemberitaan Covid-19 dibandingkan pengetahuan mengenai investasi. Hal ini didukung oleh Malik (2017) yang menunjukkan pengetahuan investasi tidak berpengaruh terhadap minat investasi di Bursa Galeri Investasi UISI. Saputra (2018) menjelaskan bahwa pengetahuan yang diberikan atau dikatakan edukasi atau pengetahuan yang diperoleh tidak memengaruhi minat investasi pasar modal di mahasiswa STIE Balikpapan. Darmawan et al., (2019) juga menujukkan bahwa pengatahuan investasi tidak berpengaruh terhadap mahasiswa Manajemen UMP angkatan 2016 dan 2017. Namun, penelitian ini berbeda dengan hasil penelitian Suyanti \& Hadi, (2019) menerangkan pengetahuan mempengaruhi dengan minat investasi pasar modal di mahasiswa ekonomi STKIP PGRI Tulungagung. Penelitian Y. Witha et al., (2020) hal ini juga menjelaskan bahwa literasi investasi mempengaruhi minat mahasiswa Universitas Papua untuk berinvestasi di pasar modal, khususnya mahasiswa FEB.

Interpretasi penelitian dapat diartikan pengetahuan dasar investasi saja dianggap tidak memberikan kecukupan dalam mendorong minat investasi generasi milenial di masa pandemi Covid-19. Waktu luang yang dilalui di rumah saja selama pandemi Covid-19 dimanfaatkan oleh mencari pengetahuan yang lainnya seperti info mengenai penyebaran Covid-19.

\section{c) Pengaruh Risiko Investasi terhadap minat Investasi Pasar Modal Generasi Milenial di Masa Pandemi Covid-19}

Hasil perhitungan menunjukkan bahwa asumsi risiko investasi $\left(\mathrm{H}_{3}\right)$ memiliki kandungan "Risiko investasi mempengaruhi minat investasi pasar modal pada generasi milenial di masa pandemi Covid-19, " sehingga hipotetis $\left(\mathrm{H}_{3}\right)$ diterima. Hal ini sesuai dengan teori Markowitz yang diterangkan bahwa adanya risiko kerugian tidak mendapatkan dividen. Penelitian ini menjelaskan adanya kesiapan generasi milenial dalam menghadapi risiko investasi yang akan terjadi. Hal ini sesuai dengan temuan penelitian Yani et al., (2020) yang menjelaskan risiko investasi memiliki pengaruh yang signifikan terhadap minat investasi di pasar modal di galeri investasi Warmadewa. Risiko investasi juga mempengaruhi minat mahasiswa ketika mereka berinvestasi di pasar modal di PT Phintraco Sekuritas Semarang (Listyani et al., 2019). Di sisi lain, hasil penelitian Wardani \& Supiati (2020) menjelaskan bahwa risiko berinvestasi tidak berpengaruh terhadap hasil investasi di pasar modal bagi mahasiswa akuntansi dan manajemen keuangan Universitas Tamansiswa Yogyakarta.

Risiko investasi mempengaruhi minat generasi milenial untuk berinvestasi di pasar modal di masa pandemi Covid-19, karena generasi milenial memiliki sikap berani terhadap pengambilan risiko, baik dari segi risiko pengembalian maupun risiko kerugian saat berinvestasi di pasar modal di masa pandemi Covid-19. Selain itu, risiko tidak memberikan 
kepastian bagi investor, sehingga generasi milenial lebih mudah menerima ketidakpastian atau risiko yang mereka hadapi saat berinvestasi di masa pandemi Covid-19.

\section{d) Pengaruh Kemajuan Teknologi terhadap minat Investasi Pasar Modal Generasi Milenial di Masa Pandemi Covid-19}

Hasil perhitungan variabel kemajuan teknologi $(\mathrm{H} 4)$ memiliki kandungan "Kemajuan teknis berpengaruh terhadap investasi di pasar modal pada generasi milenial di mas pandemi Covid-19", sehingga hipotesis kemajuan teknologi $\left(\mathrm{H}_{4}\right)$ diterima. Penelitian ini didukung oleh Cahya \& Kusuma (2019) yang menjelaskan adanya kemajuan teknologi dapat mempengaruhi minat investasi melalui "Yuk Nabung Saham" di kalangan milenial di Kabupaten Kudus. Perkembangan teknologi yang terus berubah mempengaruhi minat mahasiswa ekonomi Universitas Muhammadiyah Tangerang untuk berinvestasi di pasar modal (Negara \& Febrianto, 2020). Penelitian Tandio \& Widanaputra (2016) menerangkan kemajuan teknologi tidak berpengaruh terhadap tingkat pengembalian investasi di pasar modal di kalangan Mahasiswa FEB Universitas Udayana.

Hasil penelitian ini sejalan dengan Theory of Planned Behavior dari Kusmawati, (2011) yang menjelaskan bahwa sikap atau perilaku seseorang penting dalam menghasilkan suatu tindakan. Sikap yang dipersepsikan tentang betapa mudahnya berinvestasi di pasar modal dapat meningkatkan minat generasi milenial untuk berinvestasi. Di masa pandemi Covid-19 ini, kemajuan teknologi yang dibawa oleh perusahaan sekuritas dapat memudahkan generasi milenial untuk berinvestasi di pasar modal seperti melakukan perdagangan online (trading online) atau memperoleh informasi pasar modal melalui media sosial. Teori yang sudah dikemukakan oleh Tarigan et al., (2019) terbukti pada penelitian ini yaitu adanya fitur secara online dapat meningkatkan peran investor dalam bertransaksi di pasar modal. Milenial akan dengan mudah mengamati pergerakan pasar modal atau mengakses informasi investasi pasar modal setiap saat dengan koneksi internet di perangkat yang dimiliki.

Penelitian ini menjelaskan hasil penelitian yang didapat menunjukkan variabel risiko investasi dan kemajuan teknologi mempengaruhi terhadap minat generasi milenial untuk berinvestasi di pasar modal pada pandemi Covid-19. Sedangkan variabel motivasi dan pengetahuan investasi yang diperoleh tidak memberikan pengaruh terhadap minat investasi generasi milenial di masa pandemi Covid-19. Selanjutnya kedepannya peneliti setelah adanya penelitian ini yaitu dapat memberikan manfaat untuk pemerintah agar mendukung perkembangan investasi pasar modal yang dikarenakan tingginya minat investasi di pasar modal pada generasi milenial supaya menyimpan dananya untuk jangka panjang. Selain itu, dari hasil penelitian dapat dipakai untuk acuan akademisi atau penelitian selanjutnya.

\section{SIMPULAN}

Hasil penelitian yang sudah diuraikan, dapat disimpulkan bahwa variabel motivasi dan pengetahuan investasi tidak mempengaruhi minat berinvestasi di pasar modal pada generasi milenial di masa pandemi Covid-19. Artinya, generasi milenial tidak sepenuhnya paham untuk menginvestasikan uangnya di pasar modal, dan ilmu yang didapat selama pandemi Covid-19 menjadi prioritas untuk mempelajari lebih lanjut kasus Covid-19. Sementara itu, variabel risiko investasi dan kemajuan teknologi mempengaruhi minat generasi milenial untuk berinvestasi di pasar modal di masa pandemi Covid-19. Pengaruh ini disebabkan oleh sikap berani generasi milenial dalam mengambil keputusan dalam menghadapi ketidakpastian investasi.

Implikasi penelitian ini dapat memberikan kontribusi kepada masyarakat luas khususnya generasi milenial untuk menjadi investor pemula agar lebih tepat dalam menginvestasikan dana di masa yang akan datang. Implikasi untuk pemerintah agar pemerintah sadar dan paham adanya minat yang tinggi masyarakat untuk investasi sehingga dapat dengan mudah mendorong perusahaan untuk go public. Sedangkan bagi akademisi, penelitian ini memberikan kontrubusi sebagai pembanding dan sekaligus menjadi rujukan dalam memahami minat investasi. Keterbatasan dari penelitian ini hanya dibatasi 
dengan penggunaan empat variabel independen dan sampel hanya menggunakan 100 responden serta hanya menggunakan generasi milenial di Kabupaten Kudus saja.

Saran penelitian ini yaitu dapat dikembangkan dengan lebih banyak responden yang lebih responsif dan dalam skala besar. Penelitian ini mengharapkan generasi milenial untuk meningkatkan pengetahuannya tentang investasi pasar modal dengan mengikuti seminar/acara investasi, belajar online di jejaring sosial atau di lingkungannya sehingga termotivasi untuk berinvestasi di pasar modal. Selanjutnya, saran bagi penelitian lain dapat menambahkan variabel independen lain yang mendukung minat kaum muda dalam berinvestasi di pasar modal. Saran bagi pemerintah dapat berperan membantu kalangan muda untuk berinvestasi di pasar modal dengan menyediakan informasi yang akurat tentang investasi pasar modal atau mendukung perkembangan pasar modal melalui perusahaan publik di Indonesia.

\section{DAFT AR PUST AKA}

Aini, N., Maslichah, \& Junaidi. (2019). Pengaruh Pengetahuan Dan Pemahaman Investasi, Modal Minimum Investasi, Return, Risiko Dan Motivasi Investasi Terhadap Minat Mahasiswa Berinvestasi Di Pasar Modal (Studi Pada Mahasiswa Fakultas Ekonomi Dan Bisnis Kota Malang). E-Jra, 08(05), 38-52.

Arikunto, S. (2011). Prosedur penelitian: Suatu Pendekatan Praktik (Ed. Rev. V). Rineka Cipta.

Cahya, B. T., \& Kusuma, N. A. (2019). Pengaruh Motivasi dan Kemajuan Teknologi Terhadap Minat Investasi Saham. Al-Masharif: Jurnal IImu Ekonomi Dan Keislaman, 7, 192-207.

Darmawan, A., Kurnia, K., \& Rejeki, S. (2019). Pengetahuan Investasi, Motivasi Investasi, Literasi Keuangan Dan Lingkungan Keluarga Pengaruhnya Terhadap Minat Investasi Di Pasar Modal. Jurnal Ilmiah Akuntansi Dan Keuangan, 8(2), 44-56. https://doi.org/10.32639/jiak.v8i2.297

Deviyanti, L. P. A. E., Purnamawati, I. G. A., \& Yasa, I. N. P. (2017). Pengaruh Norma Subjektif, Persepsi Return dan Literasi Keuangan terhadap Minat Mahasiswa untuk Berinvestasi Saham di Pasar Modal (Studi Pada Mahasiswa Jurusan Akuntansi Program S1 Universitas Pendidikan Ganesha). E-Journal S1 Ak Universitas Pendidikan Ganesha, 8(2), 1-12.

Ghozali, I. (2011). Aplikasi analisis multivariate dengan program IBM SPSS 20,00. Universitas diponegoro.

Hati, S. W., \& Harefa, W. S. (2019). Analisis Faktor-Faktor Yang Mempengaruhi Minat Berinvestasi Di Pasar Modal Bagi Generasi Milenial (Studi Pada Mahasiswi Jurusan Manajemen Bisnis Politeknik Negeri Batam). Business Administration, 3(2), 281-295.

Herlianto, D. (2013). Manajemen Investasi Plus Jurus Mendeteksi Investasi Bodong. Pustaka Baru.

Hermanto. (2017). Perilaku Mahasiswa Ekonomi Di Universitas Esa Unggul Dalam Melakukan Investasi di Pasar Modal. Jurnal Ekonomi, 8(2), 1-12.

Hidayat, L., Muktiadji, N., \& Supriadi, Y. (2019). Pengaruh Pengetahuan Investasi Terhadap Minat Mahasiswa Berinvestasi Di Galeri Investasi Perguruan Tinggi. JAS-PT (Jurnal Analisis Sistem Pendidikan Tinggi Indonesia), 3(2), 63. https://doi.org/10.36339/jaspt.v3i2.215

Howe, N., \& Strauss, \& W. (2000). Millennials Rising The Next Great Generation. Vintage Book.

Huda, W. Al. (2015). Teori-Teori Motivasi. Jurnal Adabiya, Vol. 1(No. 83).

Kusmawati. (2011). Pengaruh Motivasi Terhadap Minat Berinvestasi Di Pasar Modal Dengan Pemahaman Investasi Dan Usia. Jurnal Ekonomi Dan Informasi Akuntansi (Jenius), 1(2), 103-117.

Linda Puspita Yani, K., Sara, I. M., \& Erna Trisna Dewi, A. A. . (2020). Faktor-Faktor Yang Mempengaruhi Minat Mahasiswa Dalam Berinvestasi Di Pasar Modal (Studi Kasus Pada Investor Pemula Yang Terdaftar di Galeri Investasi Universitas Warmadewa ). 
Jurnal Riset Akuntansi Warmadewa, 1(2), 37-45. https://doi.org/10.22225/jraw.1.2.1838.37-45

Listyani, T. T., Rois, M., \& Prihati, S. (2019). Analisis Pengaruh Pengetahuan Investasi, Pelatihan Pasar Modal, Modal Investasi Minimal Dan Persepsi Risiko Terhadap Minat Investasi Mahasiswa Di Pasar Modal (Studi Pada Pt Phintraco Sekuritas Branch Office Semarang). Jurnal Aktual Akuntansi Keuangan Bisnis Terapan (AKUNBISNIS), 2(1), 49. https://doi.org/10.32497/akunbisnis.v2i1.1524

Luki Zulaika, N. A. (2017). Pengaruh Pelatihan Pasar Modal, Return, Persepsi Risiko, Gender, Dan Kemajuan Teknologi Pada Minat Investasi Mahasiswa Di Pasar Modal (Studi Kasus Pada Mahasiswa S1 Akuntansi Ekstensi Di Fakultas Ekonomi Dan Bisnis Universitas Udayana). Peta, 22-35. https://sinta.unud.ac.id/uploads/wisuda/1215351039-1-HALAMAN AWAL.pdf

Malik, A. D. (2017). Analisa Faktor - Faktor Yang Mempengaruhi Minat Masyarakat Berinvestasi Di Pasar Modal Syariah Melalui Bursa Galeri Investasi Uisi. Jurnal Ekonomi Dan Bisnis Islam (Journal of Islamic Economics and Business), 3(1), 61. https://doi.org/10.20473/jebis.v3i1.4693

Mastura, A., Nuringwahyu, S., \& Zunaida, D. (2020). Pengaruh Motivasi Investasi, Pengetahuan Investasi Dan Teknologi Informasi Terhadap Minat Berinvestasi di Pasar Modal. Jiagabi, 9(1), 67-68.

Negara, A. K., \& Febrianto, H. G. (2020). GENERASI MILENIAL DI PASAR MODAI. Ekonomi, Fakultas Bisnis, Dan Muhammadiyah, Universitas, 16, 81-95.

Rahadi, D. R., \& Stevanus, Y. (2020). Persepsi Dan Pengambilan Keputusan Milenial Terhadap Instumen Investasi Masa Depan: Studi Literatur. INOBIS: Jurnal Inovasi Bisnis Dan Manajemen Indonesia, 3(2), 162-177. https://doi.org/10.31842/jurnalinobis.v3i2.129

Saputra, D. (2018). Pengaruh Manfaat, Modal, Motivasi, dan Edukasi Terhadap Minat Berinvestasi di Pasar Modal (Studi pada Mahasiswa Sekolah Tinggi IImu Ekonomi Balikpapan). Future Jurnal Manajemen Dan Akuntansi, 5(2), 178-190.

Sriasih, N., \& Wahyuni, M. (2020). Determinan Minat Berinvestasi Mahasiswa di Pasar Modal. Ekuitas : Jurnal Pendidikan Ekonomi, Volume 8(2), 190-195.

Susanti, S., Hasan, M., Ahmad, M. I. S., \& Marhawati. (2018). Faktor-Faktor yang Mempengaruhi Minat Mahasiswa Berinvestasi di Galeri Investasi Universitas Negeri Makasar. Prosiding Seminar Nasional Pendidikan Ekonomi, 4. http://eprints.unm.ac.id/11343/1/Revisi-FULL-PAPER_SARTIKA-SUSANTI.pdf

Suyanti, E., \& Hadi, N. U. (2019). Analisis Motivasi Dan Pengetahuan Investasi Terhadap Minat Investasi Mahasiswa di Pasar Modal. Edunomic Jurnal Pendidikan Ekonomi, 7(2), 108. https://doi.org/10.33603/ejpe.v7i2.2352

Tandio, T., \& Widanaputra, A. A. G. P. (2016). Pengaruh Pelatihan Pasar Modal, Return, Persepsi, Risiko, Gender, Dan Kemajuan Teknologi Pada Minat Investasi Mahasiswa. E-Jurnal Akuntansi Universitas Udayana, 16(3), 2-26.

Tarigan, H. I., Manurung, Y., \& Marpaung, W. (2019). Loyalitas Pelanggan Dan Kualitas Pelayanan Pada Pelanggan Jasa Transportasi Online. PHILANTHROPY: Journal of Psychology, 3(1), 34. https://doi.org/10.26623/philanthropy.v3i1.1285

Taufiqoh, E., Nur, D., \& Junaidi. (2019). Pengaruh Norma Subjektif, Motivasi Investasi, Pengetahuan Investasi, Persepsi Return dan Literasi Keuangan Terhadap Minat Mahasiswa Berinvestasi Saham di Pasar Modal. E-Jra, 08(05), 1-13.

Timotius Duha. (2016). Perilaku Organisasi. Deepublish.

Tumewu, F. (2019). Minat Investor Muda Untuk Berinvestasi Di Pasar Modal Melalui Teknologi Fintech. JMBI UNSRAT (Jurnal Ilmiah Manajemen Bisnis Dan Inovasi Universitas Sam Ratulangi)., 6(2), 133-145. https://doi.org/10.35794//mbi.v6i2.26170

Wardani, D. K., \& . S. (2020). Pengaruh Sosialisasi Pasar Modal dan Persepsi atas Risiko terhadap Minat Investasi Mahasiswa di Pasar Modal. Jurnal Akuntansi Maranatha, 12(1), 13-22. https://doi.org/10.28932/jam.v12i1.2044

Wi, P., \& Anggraeni, D. (2020). Faktor-Faktor Yang Mempengaruhi Minat Karyawan Perusahaan Untuk Berinvestasi Di Pasar Modal Pada Masa. Revenue, 01(01), 81-89. 
Wibowo, A. \&, \& Purwohandoko. (2019). Pengaruh Pengetahuan Investasi, Kebijakan Modal Minimal Investasi, Dan Pelatihan Pasar Modal Terhadap Minat Investasi (Studi Kasus Mahasiswa Fe Unesa Yang Terdaftar Di Galeri Investasi Fe Unesa). Jurnal IImu Manajemen (JIM), 7(1), 192-201.

Winkel, W. S. (2009). Psikologi Pengajaran. PT. Gramedia Pustaka.

Wulandari, Ay. (2020). Pengaruh Motivasi Investasi Dan Pengetahuan Investasi Terhadap Minat Investasi Mahasiswa Di Pasar Modal. Journal of Chemical Information and Modeling, $0(0), 1-12$.

Y. Witha et al. (2020). Analisa Minat Investasi Pasar Modal Pada Mahasiswa. Nominal: Barometer Riset Akuntansi Dan Manajemen, 9(2), 150-167. https://journal.uny.ac.id/index.php/nominal/article/view/30033

Yusuf, M. (2019). Pengaruh Kemajuan Teknologi dan Pengetahuan terhadap Minat Generasi Milenial dalam Berinvestasi di Pasar Modal. Jurnal Dinamika Manajemen Dan Bisnis, 2(2), 86-94. https://doi.org/10.21009/jdmb.02.2.3

www.finance.detik.com

www.ksei.co.id 